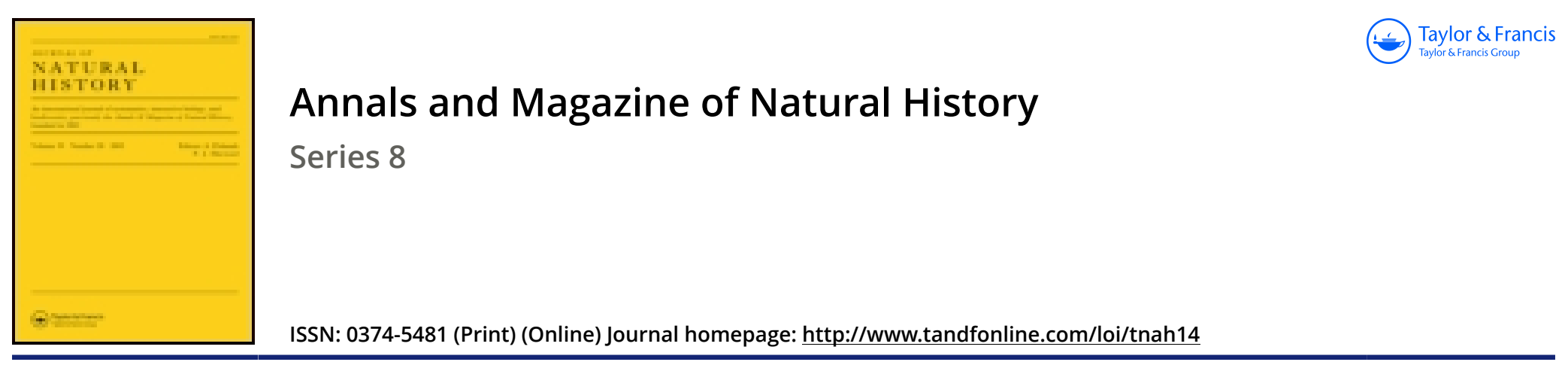

\title{
XXI._On an undescribed species of Dorcasia
}

\author{
Hugh C. Fulton
}

To cite this article: Hugh C. Fulton (1910) XXI._On an undescribed species of Dorcasia, Annals and Magazine of Natural History, 6:32, 212-212, DOI: 10.1080/00222931008692840

To link to this article: http://dx.doi.org/10.1080/00222931008692840

册Published online: 08 Sep 2009.

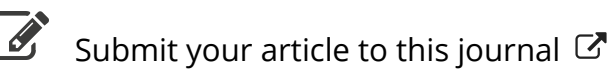

LII Article views: 1

Q View related articles $₫$ 


\section{XXI.-On an undescribed Species of Dorcasia. By Huah C. Fulton.}

\section{Dorcasia ponsonbyi, sp. $n$.}

Shell depressed globose, moderately umbilicated, rather thin, subtransparent, yellowish brown above, whitish below; whorls $4 \frac{1}{2}$, slowly increasing, nncleus almost smooth, lower whorls with rather rough and irregular oblique striæ, last whorl covered with a microscopic granular sculpture; peristome thickened, yellow, margins joined by a slightly raised reddish callus, aperture subovate, pellucid within.

Maj. diam. 27, $\min .22$; alt. $16 \mathrm{~mm}$.

Hab. Cape of Good Hope.

This shell has often been confounded with Dorcasia lucana, Mïller, from which it can be readily separated by its depressed form and microscopic granular sculpture. The specimens of lucana seen by me are more or less malleated on the last whorl, a feature that is absent in ponsonbyi, which has also half a whorl less. In some specimens the peristome is whitish, in others it is of a reddish colour.

I have much pleasure in naming this shell in honour of J. H. Ponsonby, Esq., F.Z.S., who has done so much good work in connection with the South-African molluscan fauna.

\section{XXII.-Rhynchotal Notes.-II. By W. L. Distant.}

\section{African Pentatomidæ.}

(Continued from p. 99.)

Neocrolirus, gen. nov.

Head shorter than pronotum, longer than broad, the lateral and apical margins very strongly reflexed, the lateral margins concavely sinuate, lateral lobes with their apices obtusely acute, considerably passing apex of central lobe but not meeting beyond it; eyes prominent, subpedunculate; ocelli near base, much nearer eyes than to each other; antennæ five-jointed, first joint not reaching apex of head, first and second subequal in length, third and fourth subequal, fifth longest; pronotum shorter than broad, but more than half as long as broad, the anterior margin a little con. cave, the posterior margin straightly truncate, the lateral 